\title{
MISPRICE, LEVERAGE AND STOCK BUYBACK: EVIDENCE IN INDONESIA
}

\author{
Elliv Hidayatul Lailiyah ${ }^{*}$ \\ Sekolah Tinggi Ilmu Ekonomi KH Ahmad Dahlan Lamongan, Indonesia \\ Ika Purwanti \\ Sekolah Tinggi Ilmu Ekonomi KH Ahmad Dahlan Lamongan, Indonesia \\ Muhammad Sulton \\ Sekolah Tinggi Ilmu Ekonomi KH Ahmad Dahlan Lamongan, Indonesia
}

\begin{abstract}
Cash distribution by stock buyback is one ways to increase stockholder wealth. This study is to analyze the effect of misprice (misvaluation) and leverage on stock buyback. Limited prior study discussed about stock buyback and misprice especially in Indonesia, theoritically, in Indonesia not only firm with undervalue stock do stock buyback but also firm with overvalue stock. Stock buyback can increase the stock prices, but the implementation in Indonesia is still small. Non-financial firms listed on the Indonesia Stock Exchange from 2010 to 2017 used in this study. Samples were taken by a purposive sampling method based on certain criteria. The data analysis techniques use multiple linear regression statistical analysis. The results showed that misprice has a positive effect on buyback. The different thing found in Indonesia because overvalued firms hold stock buyback. Leverage has a negative effect on stock buyback. Firms with leverage below the target tend to do a stock buyback. In addition, the stock buyback also used to correct prices (for undervalued stock to be fair). The implication in this study is stock buyback not only viewing to correct prices but also giving a signal to the market that the firm is in a good fundamental condition.
\end{abstract}

JEL : G23, G32, G35

Keywords : stock buyback, misprice, leverage.

\begin{abstract}
ABSTRAK
Distribusi uang tunai melalui pembelian kembali saham merupakan salah satu cara untuk meningkatkan kekayaan pemegang saham. Penelitian ini bertujuan untuk menganalisis pengaruh misprice (misvaluation) dan leverage terhadap pembelian kembali saham. Penelitian terdahulu terbatas membahas tentang buyback dan misprice saham khususnya di Indonesia, secara teoritis di Indonesia tidak hanya perusahaan dengan saham undervalue yang melakukan buyback saham tetapi juga perusahaan dengan saham yang overvalue. Pembelian kembali saham dapat meningkatkan harga saham, namun implementasinya di Indonesia masih sedikit. Perusahaan non keuangan yang terdaftar di Bursa Efek Indonesia dari tahun 2010 hingga 2017 digunakan dalam penelitian ini. Pengambilan sampel dilakukan dengan metode purposive sampling berdasarkan kriteria tertentu. Teknik analisis data menggunakan analisis statistik regresi linier berganda. Hasil penelitian menunjukkan bahwa misprice berpengaruh positif terhadap pembelian kembali saham. Hal berbeda ditemukan di Indonesia karena perusahaan yang overvalued melakukan buyback saham. Leverage berpengaruh negatif terhadap pembelian kembali saham. Perusahaan dengan leverage dibawah target cenderung melakukan buyback saham. Selain itu, pembelian kembali saham juga digunakan untuk mengoreksi harga (agar saham yang undervalued menjadi wajar). Implikasi dalam penelitian ini adalah buyback saham tidak hanya melihat harga yang benar tetapi juga memberikan sinyal kepada pasar bahwa perusahaan berada dalam kondisi fundamental yang baik.
\end{abstract}

Kata Kunci : pembelian kembali saham, misprice, leverage.

\section{INTRODUCTION}

The firm runs its business aimed to maximize firm value. Firm value is important because it will increase stockholder wealth. Stockholders always want their wealth to increase, one of the

\footnotetext{
*Email : ellivhidayatullailiyah@gmail.com

Received : 23-07-2020, Accepted: 25-08-2020, Published : 28-08-2020

P-ISSN : 2087-9954, E-ISSN : 2550-0066. DOI: http://dx.doi.org/10.26418/jebik.v9i2.41547
} 
ways is by distributing cash to them. One part of the cash distribution to stockholders is stock buyback. The firm can distribute cash to stockholders through dividend payments and or stock buyback. It mean that stock buyback is an alternative to dividend payments. Eisenhardt (1989) define stock buyback as a transaction where a firm buyback a portion of a firm's stock, this purchase will have an impact on reducing the number of stock outstanding, thereby increasing earnings per share (EPS) and increasing the firm's stock price. Stock buyback were used to boost earnings per share (EPS) temporarily (Abraham, Harris, \& Auerbach, 2018 ; Stunda, 2017 ; Lei \& Zhang, 2016 ; Manconi, Peyer, \& Vermaelen, 2018 ; Bargeron, Bonaime, \& Thomas, 2017). Mukherjee \& Chatterjee (2019) find the different that on average firm in India do not experience price improvement after stock buyback.

Stock buyback is a firm to buy back the stock from its own stockholders (Brealey, Myers, $\&$ Marcus, 2015). One of the benefits of stock buyback is a flexible form of cash distribution because stock buyback is not a firm commitment. This is different from sticky dividends because the market will impose penalties on firms that reduce or not pay dividends (Lailiyah \& Soeharto, 2019). Ross, Westerfield, \& Jordan (2013) state that stock buyback are typically accomplished in one of the ways. First firms may simply purchase their own stock or open market purchased. Second, the firm could institute a tender offer and the last, firm may buyback the stock from specific individual stakeholder (called targeted repurchase).

Other countries have developed rapidly regarding stock buybacks. When a firm announces stock buyback, it signals to the market that it is financially and fundamentally strong and it has better and bright prospects in the future. The market normally reacts to the positive information of the announcement of buyback positively. As a result, the stock price of the firm moves upward (Rane, 2019). Empirical data in Indonesia, states that during the period of eight years between 2010 and 2017, there were only 125 stock buyback events carried out by only 70 non-financial firms, whereas the average number of non-financial firms that have been listed on the Indonesia Stock Exchange was taken from 2010 to 2017 as many as 421 firms. It means that this number is relatively small because only around 16.63 percent of non-financial firms conduct stock buyback in a span of eight years. When viewed in detail, in Indonesia there are only a few annual stock buyback events in 2010 to 2017, between 0.83 percent to a maximum of 6.70 percent, whereas stock buyback can increase stock prices but their implementation in Indonesia is significantly small.

Research has devoted significant attention to understanding of misprice and stock buybacks. Usman, Saleem, Mahmood, \& Imran (2018) state that misprice affects corporate investment decisions. The firm does a stock buyback due to misprice or misvaluation of the stock. In this study, the market to book ratio is a proxy for misprice or misvaluation. Dittmar (2000) revealed that a low market to book ratio indicates that the firm will get excess returns in the next period. Dittmar (2000) also adds that the market to book ratio can indicate that a firm's stock is undervalued. ( Andriosopoulos \& Lasfer (2015); Bonaimé, Öztekin, \& Warr (2014) also add that this is in line with the market timing hypothesis, in which the firm will buyback the stock when firm stock are low or undervalued.

The research findings show that the market to book ratio has a negative effect on stock buyback (Dittmar, 2000 ; Mitchell \& Dharmawan, 2007; Oswald \& Young, 2008; Jiang, Kim, Lie, \& Yang, 2013; Teng \& Hachiya, 2013). This means that when a firm has a low market to book 
ratio (the value is below one) and is in undervalued condition, then the firm doing a stock buyback will be even higher. Different results were found by Jansson \& Larsson-Olaison (2010), C. I. Lee, Ejara, \& Gleason (2010), B. S. Lee \& Suh (2011) and Andriosopoulos \& Lasfer (2015) which stated that the market to book ratio did not affect the stock buyback. The firm will try to increase its leverage ratio so that the firm value increases. This can occur due to greater tax savings. Stock buyback can be used as a way to increase leverage ratios. When the firm distributes its cash by doing stock buyback, the firm's equity level will decrease while the level of debt remains constant. This conditions will make the ratio of debt and equity of the firm higher. Firms will prefer to do a stock buyback if their leverage ratio or debt level is below the target (Dittmar, 2000).

The research findings get the result that leverage negatively affects the stock buyback. This means that the lower the leverage ratio of a firm, the possibility of a firm doing a stock buyback will be higher (Dittmar,2000; Mitchell \& Dharmawan, 2007; Oswald \& Young, 2008; Jansson \& Larsson-Olaison, 2010; B. S. Lee \& Suh, 2011; Jiang et al., 2013; Houcine, 2013; Yarram, 2014). Research by Andriosopoulos \& Hoque (2013) and Teng \& Hachiya (2013) found a different finding that leverage had no effect on stock buyback. Firm size (SIZE) is used as a control variable (Boudry, Kallberg, \& Liu, 2013 ; Houcine, 2013). Firm size describes the size of a firm. The greater the number of assets, the greater the size of a firm. Firm size also illustrates the financial capabilities of large firms so as to make the firm's ability to do stock buyback is also large. This research will reveal the effect of misprice (MSRP) and leverage (LEV*) on stock buybacks (SBUY). The sample used is non-financial firms listed on the Indonesia Stock Exchange which carried out stock buybacks in the period 2010-2017. Different things are found in Indonesia, not only companies with undervalued shares who did stock buyback, but also overvalued companies also hold stock buyback. Therefore, the implication in this study is stock buyback should not only be seen to correct prices but also as a signal to the market that the company is in good fundamental condition.

\section{LITERATURE REVIEW}

\subsection{Regulations}

Each country has different regulations regarding stock buyback. In Indonesia, regulations regarding stock buyback issued by publicly listed firms are generally regulated by Bapepam and LK rule number XI.B.2 of 1998 and amended by Attachment to the Decree of the Chairman of Bapepam and LK number: Kep-105 / BL / 2010 dated April 13, 2010. The regulation requires firms to announce a stock buyback plan in advance and obtain approval at the AGM (Annual General Meeting of Stockholders) before making a stock buyback.

The enactment of law number 21 of 2011 concerning the Financial Services Authority (in Indonesia called OJK) then all functions, duties and authority of Bapepam and LK are transferred to OJK. On August 23, 2013 OJK issued the Financial Services Authority Regulation (called POJK) No. 2/POJK.04/2013 concerning the buyback of stock issued by public firms in a market condition that fluctuated significantly. This regulation was made to facilitate public firms in carrying out corporate actions in the form of stock buyback without violating applicable regulations or laws. In addition there is also SE OJK Regulation Number 1/SEOJK.04/2013 which is an additional provision for the implementation of POJK Number 2 / POJK.04 / 2013 which explains conditions other than those stipulated in the POJK. OJK also issued POJK Number 
30/POJK.04/2017. This regulation is a clear and definite rule from OJK regarding the stock buyback arrangement conducted by a public firm after the formation of the OJK.

\subsection{Agency Theory and Stock Buyback}

Jensen \& Meckling (1976) define agency relationships, namely one or more individuals, principals, contracting or employing one or more other individuals, agents to carry out certain tasks accompanied by delegation of authority. Jensen \& Meckling (1976) explain that firms are very vulnerable to agency conflict if the firm separates management and ownership functions. This is because the interests of each party conflict with each other, that is, each party always tries to achieve its desires and prosperity. The goal of minimizing conflict between principals and agent, will be achieved if the principal and agents make an agreement, namely by setting the proportion of the rights and duty of each, so that the goal is expected to maximize the utility of the principals, and can satisfy and guarantee the agents to get rewards or rewards from his work in managing the firm.

Eisenhardt (1989) assumes that different interests between principals and agents can lead to agency conflicts. Problems will arise if the principal cannot know the activities carried out by agents in the firm. The existence of a conflict of interest between agents and principals in a firm is called an agency problem. Conflicts that occur can be reduced by issuing costs, namely agency costs. The agency problem in this study is related to fulfilling the interests of the firm's stockholders. Stock buyback is an alternative in resolving agency conflicts between stockholders (principals) and managers (agent).

\subsection{Misprice and Stock Buyback}

Chee (2018) and Bin \& Razak (2019) state that managers must observed and learned information from firm-specific variation in stock return and stock price when performing open market repurchase or stock buyback. Information from stock price or financial statement can help managers to determine the financial decision in a firm. The firm made a stock buyback due to misprice or misvaluation. The positive stock price reaction at the announcement of a stock buyback should correct the misprice or misvaluation (Vermaelen, 1981). Misprice or misvaluation (MSPR) in this study is proxied by the market to book ratio. Market to book ratio is defined as a ratio that compares the magnitude of the book value of stocks and stock market prices. The use of market to book ratios can show whether a firm's stock is experiencing misprice or misvalued (undervalued or overvalued) or not. A low market to book ratio (the value is below one) indicates that the firm is in an undervalued condition, which is where the stock market price is below the book value. Conversely, a high market to book ratio (the value is above one) shows that the firm is in an overvalued condition, which is where the stock market price is above the book value.

The high value of the market to book ratio indicates that the market has an excessive perception of the value of the firm, conversely the lower value of the market to book ratio can be interpreted as a signal of a good investment opportunity in the long run. If the firm's stocks go undervalued, it can cause a continued decline in stock prices, in order to avoid such a decline the firm can withdraw stocks with a stock buyback. The market timing hypothesis supports this: the firm will issue stocks if the firm's stock price is high or overvalued and will buyback the stock when the firm's stock is low or undervalued. 
The undervaluation hypothesis and signaling hypothesis are based on the premise that there is information asymmetry between insiders and stockholders that can cause firms to be misvalued (Dittmar, 2000). The research of Ong \& Ng (2018) find a significant positive abnormal return in buyback announcements and consistent with the signaling hypothesis that shows stock buyback announcement can be an effective tool in stabilizing the stock market. A stock to be undervalued if the market value of the stock is lower than the true value. This conditions provide a separate investment advantage for investors because they can buy stocks at a lower price and sell them at a higher price (Lailiyah \& Soeharto, 2019). If the firm believes that the firm's stocks are undervalued, the firm can do a stock buyback which is used as an information signal to the market that the firm's stock are in an undervalued condition. Stock buyback will reduce the outstanding stocks so that demand for stock is higher and high demand can cause stock prices to rise, so it can be said that stock buyback is a way to correct misvalued stock prices so that prices become reasonable.

Dittmar (2000) explains that in the case of undervaluation, firms must have a stock price less than the true value, of course it will be difficult to determine with certainty if the firm is experiencing undervalued. One indication of undervaluation is the history of low returns. Dittmar (2000) revealed that firms with a low market to book ratio will get a higher return in the next period. This means that the market to book ratio can indicate that a firm has the potential to experience undervaluation. Dittmar's interpretation assumes that the abnormal performance of stock values is due to the misvaluation of expected returns.

A low market to book ratio (less than one) indicates that the firm is undervalued. Stock buyback causes stock demand to be higher than supply and causes stock price to rise. Stock buyback is used to correct prices by increasing undervalued stock prices so prices are reasonable. Stock buyback also conveys a positive signal to the public that the firm's stocks in the future have good prospects in the future so that with a positive reaction from the public it will be able to increase the firm's stock price (Rane, 2019). Based on the description and results of previous studies, the first hypothesis $\left(\mathrm{H}_{1}\right)$ in this study is market to book ratio as a proxy for misprice (misvaluation) has a negative effect on stock buyback. When a firm has a low market to book ratio (the value is below one) and is in an undervalued condition, the number of stocks withdrawn will increase. This is supported by the results of research (Dittmar, 2000; Mitchell \& Dharmawan, 2007; Oswald \& Young, 2008; Jiang et al., 2013; Teng \& Hachiya, 2013).

\subsection{Leverage and Stock Buyback}

Leverage ratios measure how much a firm spends using debt. This study follows the research of Jansson \& Larsson-Olaison (2010) and Mitchell \& Dharmawan (2007) who use debt to equity ratio (D/E) in explaining leverage variables. Debt to equity ratio was chosen because this research is related to stock buyback, where the implementation of stock buyback in this study will affect the firm's equity rather than the amount of debt used for the implementation of stock buyback. The debt to equity ratio measures how much or how little debt is used compared to the size of the firm's own capital. If the firm's leverage ratio is below the target (underleverage), the firm can do a stock buyback so that the leverage ratio increases or can also increase expansion by making loans. Stock buyback will reduce the outstanding stocks so that the firm's equity decreases but with a fixed level of debt, so the leverage ratio will increase. Conversely, if the leverage ratio 
is above the target leverage ratio (overleverage), the firm should not add debt and not buyback the stock because it can cause the firm to experience financial difficulties and bankruptcy.

Static trade-off theory suggests that firms will use debt to a certain point when the amount of tax shield from debt is proportional to the cost of financial distress. Based on this it can be said that this theory balances the benefits of taxes with the sacrifice of costs incurred due to debt. Firms will use debt to a certain extent, and will stop debt if the tax benefits are lower than the risk of bankruptcy, because it will increase the risk of the firm. The use of debt is used because the cost of interest from the debt can be deducted in calculating the tax. Based on this theory, it can be said that the capital structure can be said to be optimal if the capital structure balances the return (benefit) and risk (cost), thus the stock price or the value of the firm will be maximized.

The optimal leverage hypothesis states that the firm carries out a stock buyback as a way to increase its debt ratio (to achieve an optimal capital structure). This means that firms with a leverage ratio below the target tend to do a stock buyback than firms that have an optimal capital structure. The firm analyzes a number of factors and then will set a target capital structure. This target may change due to changes in conditions, but in management's mind there is always a shadow of the target capital structure and each payment must be consistent with the target. This study also follows the research of Dittmar (2000) in relation to leverage variables, namely leverage affecting stock buyback through leverage deviation (LEV*), so that leverage in this study is proxied by leverage deviation $\left(\mathrm{LEV}^{*}\right)$.

Firm leverage ratio calculated by total debt to total equity. Thus Target leverage ratio calculated by median firm leverage ratio of all firms in one industry. The firm will try to increase its leverage ratio so that the firm's value increases. This can occur due to greater tax savings. Stock buyback can be used as a way to increase leverage ratios. When the firm distributes its cash by doing stock buyback, the firm's equity level will decrease while the level of debt remains constant. This condition means the ratio of debt and equity ratio of the firm will be higher. This study uses leverage deviation $\left(\mathrm{LEV}^{*}\right)$ as a proxy for leverage. Firms will prefer to do a stock buyback if their leverage ratio or debt level is below the target. In this research,the second hypothesis $\left(\mathrm{H}_{2}\right)$ is leverage has a negative effect on stock buyback. The low leverage ratio of a firm will make the stock buyback higher. Research by Dittmar (2000) ; Mitchell \& Dharmawan (2007); Oswald \& Young (2008); Jansson \& Larsson-Olaison (2010); B. S. Lee \& Suh (2011); Jiang et al. (2013); Houcine (2013); Yarram (2014) also support this.

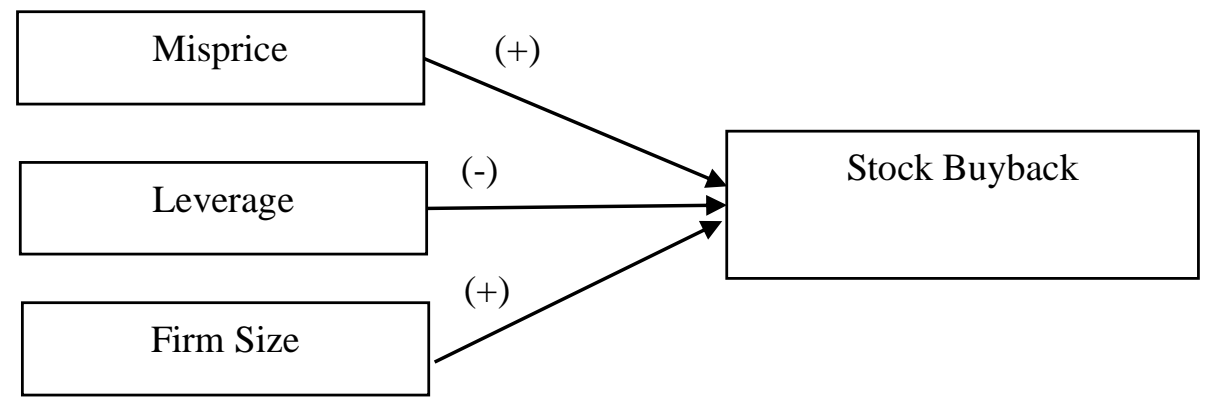

Figure 1. Research Framework 


\section{RESEARCH METHOD}

The sample used in this study is non-financial companies listed on the Indonesia Stock Exchange in 2010-2017. Samples were taken using a purposive sampling method, based on certain criteria, as follows : the company is a non-financial company listed on the Indonesia Stock Exchange in 2009-2017; the company conducted a stock buyback between 2010-2017; the sample taken is the year the company carried out a stock buyback; the company publishes its financial statements and information needed in this study during the period 2009-2017; and the company has positive free cash flow. Based on the sample criteria, 54 firms obtained stock buyback and 92 observations were obtained for the analysis model that was compiled. Data analysis techniques in this study used multiple linear regression analysis to determine the relationship between the independent variables on the dependent variable. The following table describe how each variable is measured :

Table 1. Variable Measurement

\begin{tabular}{|c|c|c|}
\hline & Variable & Measurement \\
\hline \multicolumn{3}{|c|}{ Dependent Variable } \\
\hline 1 & Stock Buyback (SBUY) & $\begin{aligned} \text { SBUY }_{\text {it }}= & \text { LN (The number of stock buyback in } \\
& \text { rupiah units } \\
(\text { it) } & \text { ) }\end{aligned}$ \\
\hline \multicolumn{3}{|c|}{ Independent Variable } \\
\hline 2 & $\begin{array}{l}\text { Misprice (MSPR) proxied by } \\
\text { market to book ratio }\end{array}$ & $\operatorname{MSPR}_{(\mathrm{t}-1)}=\frac{\text { Market Price perShare }(\mathrm{t}-1)}{\text { Book Value perShare }(\mathrm{t}-1)}$ \\
\hline \multirow[t]{2}{*}{3} & $\begin{array}{l}\text { Leverage }\left(\mathrm{LEV}^{*}\right) \text { proxied by } \\
\text { leverage deviation }\end{array}$ & $\begin{aligned} \mathrm{LEV}_{(\mathrm{t}-1)}= & \text { Firm Leverage Ratio }(\mathrm{t}-1) \text {-Target } \\
& \text { LeverageRatio }(\mathrm{t}-1)\end{aligned}$ \\
\hline & & 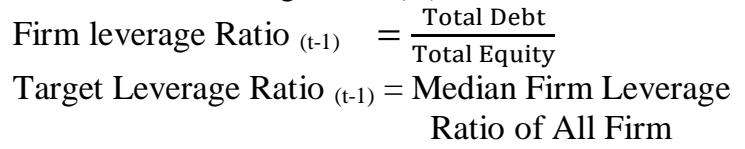 \\
\hline \multicolumn{3}{|c|}{ Control Variable } \\
\hline 4 & Firm Size & $\operatorname{SIZE}_{(\mathrm{t}-1)}=\operatorname{Ln}($ Total Asset $)$ \\
\hline
\end{tabular}

To test the hypothesis discussed above with the following analysis model for each sample year using cross-sectional data:

$S B U Y_{i t}=\alpha+\beta 1 M S P R_{i(t-1)}+\beta 2 L E V^{*}{ }_{i(t-1)}+\beta 3 S I Z E_{i(t-1)}+\varepsilon_{i t}$

Note:

$S B U Y_{i t} \quad=$ stock buyback of firm i period $\mathrm{t}$,

$\alpha \quad=$ constant,

$\beta_{1-3} \quad=$ coefficient value,

$M S R P_{i(t-1)} \quad=$ market to book ratio of firm i period $\mathrm{t}-1$,

$L E V^{*}{ }_{i(t-1)} \quad=$ deviation of corporate leverage i period $\mathrm{t}-1$,

$S I Z E_{i(t-1)} \quad=$ size of firm i period $\mathrm{t}-1$,

sit $\quad=$ error.

\section{RESULT AND DISCUSSION}

Researchers have tested the classical assumptions with the agreed analysis model above. The classical assumption test results have fulfilled so that the data is normally distributed, does not contain multicollinearity, does not contain heteroscedasticity and there is no autocorrelation. 
Table 2. Results of regression analysis of stock buyback

\begin{tabular}{|c|c|}
\hline & Coefficient \\
\hline \multicolumn{2}{|l|}{ Independent variable } \\
\hline Konstanta & -1.726 \\
\hline MSRP & $0.190^{* *}$ \\
\hline $\mathrm{LEV}^{*}$ & $-0.944^{*}$ \\
\hline SIZE & $0.866^{*}$ \\
\hline $\mathrm{N}$ & 92 \\
\hline $\mathrm{R}^{2}$ & 0.683 \\
\hline
\end{tabular}

${ }^{*}$ Significant at $1 \%,{ }^{* *}$ Significant at $5 \%$

Based on the results, the coefficient of market to book ratio (MSRP) is 0.190 has a positive effect on stock buyback (SBUY) significant $<0.05$. The results of this analysis do not support or do not prove the first hypothesis which states that the market to book ratio has a negative effect on stock buyback. The theory and results of previous studies reveal that stock buyback is used by firms whose stocks are undervalued so that the stock price rises and becomes fair. Different things are found in Indonesia that misprice (misvaluation) has a positive effect on stock buyback. In this study there are stocks that experience undervaluation but stocks are in a more overvalued condition statistically show a positive effect.

In line with the research of Lee, Park, \& Pearson (2020) suggest that a large fraction of recent stock buybacks has not been motivated by fundamentals based reasons such as undervaluation. In Indonesia, the implementation of stock buyback also not influenced by undervalued stocks, because firms in Indonesia do not do buyback the stock only when undervalued (market prices are below book value). This can be seen from the market to book ratio value of sample firms that carry out stock buyback shows an average value above the value of one which means that the stock is overvalued (the market price is above the book value). There are 62 out of 92 observations that indicate the stock overvalued, while 30 others are undervalued stocks that buyback to increase or correct the market price of the stocks to be reasonable.

Firms that overvalues does the stock buyback because they have excess cash generated by the firm. In addition, firms that buyback their stocks in an overvalued condition give a positive signal to the market that the firm is in good fundamental condition and is performing well (Lailiyah \& Soeharto, 2019). The firm's confidence in its fundamental condition can be seen from the firm being able to buyback its overvalued stocks with an additional premium which is certainly not insignificant to attract stockholders to sell their stock ownership to the firm. This finding in Indonesia is an unusual thing, where overvalued firms continue to stock buyback. This is because when a stock is overvalued and then buyback the stock, it is likely that the stock price will be increasingly over priced.

Market to book ratio can also be used to see growth opportunity. That is, a high market to book ratio (overprice) also shows a high growth opportunity in the future. In addition, according to Healy \& Palepu (1993), overprice or overvalues are bad news which means the current market conditions are not as good as the perception, by doing a stock buyback the firm proves that the firm is really in good fundamental condition. In conclusion, firms whose stocks are undervalued see stock buyback as a way to correct prices (increase prices) and be used as investments that will be more profitable for the firm because they will provide benefits (i.e. the difference or price difference when buying at low prices and selling when prices have started to rise). Unlike firms 
whose stocks are overvalued, do not see the stock buyback as an investment (because later prices will fall close to the book value) but as a signal to the market that the firm's condition is good.

The results in this study do not support the results of research by Jansson \& LarssonOlaison (2010); B. S. Lee \& Suh (2011); Andriosopoulos \& Hoque (2013) which states that the market to book ratio has no effect on stock buyback. Based on the results of the multiple linear regression shows that the coefficient of deviation of leverage (LEV*) from the target leverage is 0.944 significant $<0.01$. LEV* has a negative effect on the stock buyback (SBUY). This means that the lower the leverage ratio of a firm, the higher stock buyback will be. These results prove the second hypothesis in this study which states that leverage negatively affects the stock buyback.

The results of this research analysis show that the average sample firm that stock buyback in Indonesia has a leverage ratio below the target leverage (there are 56 out of 92 observations with a minus value). This target is the median of leverage in one industry. Firms that are below the target are trying to achieve an optimal capital structure. The optimal capital structure is achieved if the firm's leverage is not below the median leverage in one industry. This is the reason why firms reduce their equity by stock buyback so that their debt to equity ratio increases so that the firm's leverage is not below the target. This is support the optimal leverage hypothesis. The firm in this study will reduce equity and not increase the amount of debt in increasing leverage. The results of this study also support previous studies such as Dittmar (2000), Mitchell \& Dharmawan (2007), Oswald \& Young (2008), Jansson \& Larsson-Olaison (2010), B. S. Lee \& Suh (2011), Jiang et al. (2013), Houcine (2013) and Yarram (2014) who found that leverage has a negative effect on stock buyback.

\section{CONCLUSION AND RECOMMENDATION}

So far, stock buyback is associated with investment motives (stock buyback is an alternative investment if there is no other profitable investment). In addition, the stock buyback is also used to correct prices (for undervalued stocks to be fair). A different thing is found in Indonesia, that not only firms with undervalued stocks do it, but overvalued firms also hold stock buyback. Therefore, the implication in this study is that stock buyback should not only be seen to correct prices but also as a signal to the market that the firm is in good fundamental condition. In addition, the firm must also pay more attention to dividend policy, the right capital structure, and timing of stock buyback because it will affect the reaction of the market. The implementation of stock buyback will provide benefits in achieving the objectives of the firm, namely maximizing the wealth of the stockholders.

There are several limitations in this study. The number of research samples in a period of eight years is small. This is because in Indonesia there are few companies that do stock buyback annually. This study only uses two independent variables and one control variable and also limits companies that only have positive free cash flow. Future studies are expected to increase the period of research so that the sample obtained is getting bigger, and will provide results that can describe the actual conditions. Further research expect to use other variables such as adding macro factors such as economic conditions when the firm carries out stock buyback, so as to provide a broader view. 


\section{REFERENCES}

Abraham, R., Harris, J., \& Auerbach, J. (2018). Determinants and Consequences of Share Repurchase Decisions. Modern Economy, 09(05), 966-979.

Andriosopoulos, D., \& Hoque, H. (2013). The Determinants of Share Repurchases in Europe. International Review of Financial Analysis, 27, 65-76.

Andriosopoulos, D., \& Lasfer, M. (2015). The Market Valuation of Share Repurchases in Europe. Journal of Banking and Finance, 55, 327-339.

Bargeron, L., Bonaime, A., \& Thomas, S. (2017). The Timing and Source of Long-Run Returns Following Repurchases. Journal of Financial and Quantitative Analysis.

Bin, H., \& Razak, A. (2019). Effect of Stock Price Information on Timing of Share Repurchases: EBSCOhost. 4(1), 36-46.

Bonaimé, A. A., Öztekin, O., \& Warr, R. S. (2014). Capital Structure, Equity Mispricing, and Stock Repurchases. Journal of Corporate Finance, 26, 182-200.

Boudry, W. I., Kallberg, J. G., \& Liu, C. H. (2013). Investment Opportunities and Share Repurchases. Journal of Corporate Finance, 23, 23-38.

Brealey, R. A., Myers, S. C., \& Marcus, A. J. (2015). Long-Term Financial Planning. In Fundamentals of Corporate Finance.

Chee, C. (2018). Open Market Repurchases And Stock Price Informativeness: Evidence From Malaysia. 5, 107-125.

Dittmar, A. K. (2000). Why Do Firms Repurchase Stock? Journal of Business, 73(3), 331-355.

Eisenhardt, K. M. (1989). Agency Theory: An Assessment and Review. The Academy of Management Review, 14(1), 57-74.

Healy, P. M., \& Palepu, K. G. (1993). The Effect of Firms' Financial Disclosure Strategies on Stock Prices. Accounting Horizons.

Houcine, R. El. (2013). Ownership Structure and Stock Repurchase Policy: Evidence From France. 5(2), 45-55.

Jansson, A., \& Larsson-Olaison, U. (2010). The Effect Of Corporate Governance on Stock Repurchases: Evidence From Sweden. Corporate Governance: An International Review, 18(5), 457-472.

Jensen, N., \& Meckling, W. (1976). Theory of The Firm: Managerial Behavior, Agency Costs, and Capital Structure. Journal of Financial Economics.

Jiang, Z., Kim, K. A., Lie, E., \& Yang, S. (2013). Share Repurchases, Catering, And Dividend Substitution. Journal of Corporate Finance, 21(1), 36-50.

Lailiyah, E. H., \& Soeharto, S. M. (2019). Determinan Share Repurchase pada Perusahaan Non Keuangan yang Terdaftar di Bursa Efek Indonesia. Arthavidya, 21(1), 1-19.

Lailiyah, E. H., \& Soeharto, S. M. (2019). Motif Perusahaan dalam Stock Repurchase Firm's Motives in Stock Repurchase. Forum Ekonomi, 21(2), 119-125.

Lee, B. S., \& Suh, J. (2011). Cash Holdings and Share Repurchases: International Evidence. Journal of Corporate Finance, 17(5), 1306-1329.

Lee, C. I., Ejara, D. D., \& Gleason, K. C. (2010). An Empirical Analysis of European Stock Repurchases. Journal of Multinational Financial Management, 20(2-3), 114-125. 
Lee, I., Park, Y. J., \& Pearson, N. D. (2020). Repurchases After Being Well Known as Good News. Journal of Corporate Finance, 62.

Lei, Z., \& Zhang, C. (2016). Leveraged Buybacks. Journal of Corporate Finance, 39, 242-262.

Manconi, A., Peyer, U., \& Vermaelen, T. (2018). Are Buybacks Good for Long-Term Shareholder Value? Evidence from Buybacks around the World. Journal of Financial and Quantitative Analysis, 54(5), 1899-1935.

Mitchell, J. D., \& Dharmawan, G. V. (2007). Incentives for on-Market Buy-Backs: Evidence From A Transparent Buy-Back Regime. Journal of Corporate Finance, 13(1), 146-169.

Mukherjee, P., \& Chatterjee, C. (2019). Does Share Repurchase Announcement Lead to Rise in Share Price? Evidence from India. Global Business Review, 20(2), 420-433.

Ong, T. S., \& Ng, P. S. (2018). The Effects of Share Repurchase Announcements on Returns in the Malaysia Stock Market. Indonesian Journal of Business Finance and Accounting, 1(1).

Oswald, D., \& Young, S. (2008). Share Reacquisitions, Surplus Cash, and Agency Problems. Journal of Banking and Finance, 32(5), 795-806.

Rane, P. U. (2019). Stock Market Reaction to The Buyback Announcement--An Abnormal Returns Analysis. Global Journal for Research Analysis, 8(9), 32-38.

Ross, S., Westerfield, R. W., \& Jordan, B. D. (2013). Fundementals of Corporate Finance 10e. In McGraw-Hill Irwin: New York.

Stunda, R. (2017). Corporate Stock Buybacks-Do They Enhance or Worsen Company Performance over Time? Quarterly Journal of Finance and Accounting, 55(1/2).

Teng, M., \& Hachiya, T. (2013). Agency Problems and Stock Repurchases: Review of Pacific Basin Financial Markets and Policies, 16(3).

Usman, M., Saleem, S., Mahmood, F., \& Imran, H. (2018). Does Stock Mispricing Affect the Corporate Investment Decisions? Evidence From Catering Effect. Journal on Innovation and Sustainability, 9(1), 43-54.

Vermaelen, T. (1981). Common Stock Repurchases and Market Signalling. An Empirical Study. Journal of Financial Economics, 9(2), 139-183.

Yarram, S. R. (2014). Factors Influencing on Market Share Repurchase Decisions in Australia. Studies in Economics and Finance, 31(3), 255-271. 